liquid helium at about $-269^{\circ} \mathrm{C}$. The Company's activities do not as yet cover the whole of this range, but the booklet makes it clear that the Company rightly regards itself as being in the vanguard of resoarch on the applications of fluids: "We are already extremely well versed in the idiosyncracies of fluids, from hot engine gases down to those at very near absolute zero". Hymatic claim that since 1955 they have been pioneers in the field of cryogenic engineering, the study and control of very low temperature down to about $4^{\circ} \mathrm{K}$. "There are innumerable applications for low temperature equipment, military, commercial and in research. First, information applications-masers and lasers, computer cryotrons and infra-red detectors; secondly, power applications-transmission by superconducting cables and high magnetic field production for superconducting solenoids in plasma physics; and lastly, a broader field of research applications in solid-state physies, space chambers and bubble chambers." The Company considers the science of cryogenics so important to-day that it has joined with three other companies active in this field to form a new consortium, Cryosystems, Ltd., with the view of developing and manufacturing equipment, at the same time undertaking a continuing programme of original research in this modern discipline. This little publication is profusely illustrated, much of it in colour, and presents the reader with a realistic approach to the frontiers of a subject still only in its infancy.

\section{Varian Fellowship}

VARIAN A.G. is inviting applications from physicists and chemists who have recently obtained the degree of Ph.D. for its 1966 Fellowship. The successful candidate, who will be awarded 6,000 dollars, will spend twelve months in the Varian Research Laboratories in Zurich, commencing in autumn 1965. There he may continue work in the field of his thesis or can carry out research in a new field with one of the Varian staff. Problems involving the aid of magnetic and electron resonances are of special interest, as are those concerning solid-state physics with nuclear resonance. Further information prior to application can be obtained from Varian Associates, Ltd., Russell House, Molesey Road, Walton-on-Thames, Surrey. Applications should be sent to Dr. W. G. Proctor, Varian A.G., Klansstrasse 43, Zurich 8.

\section{Gordon Research Conferences, 1965}

THE Gordon Research Conferences, which are designed to stimulate research in universities, research foundations and industrial laboratories, will be held this year at five locations in New Hampshire during June 14-September 3. Fifty-four five-day conferences will be held, covering a wide range of topies in the physical and biological sciences. The purpose of the Conferences is to discuss the latest scientific developments, analyse their significance, and provoke suggestions for further research. Residence and registration charges for each Conference will amount to 115 dollars. Further information and forms of application can be obtained from Dr. W. George Parks, director, Gordon Research Conferences, University of Rhode Island, Kingston, Rhode Island.

\section{University News :}

Birmingham

THe following appointments have been announced: Senior Lectureships, Mr. W. R. H. Batty, Dr. E. J. Forbes, Dr. C. R. Patrick and Dr. L. F. Thomas (chemistry); Dr. R. W. Murray (zoology and comparative physiology); Dr. C. E. Harrold (botany); Dr. R. G. O. Kekwick and Dr. F. W. J. Teale (biochemistry); Dr. K. B. Haley (engineering production); Dr. D. C. Cooper (electronic and electrical engineering); Mr. J. W. Carter (chemical engineering); Mr. A. G. Gregory (mining and minerals engineering); Lectureships, Mr. M. C. Lewis (botany); Dr. R. T. Walker and Dr. D. W. Davies (chemistry); Mr. D. J. Creasey (electronic and electrical engineering);
Dr. R. Coleman (medical biochemistry and pharmacology); Dr. J. H. Pearce (microbiology); Dr. B. L. Reece (physics); Research Fellowships, Dr. J. Betts and Dr. K. Toth (chemistry).

London

DR. J. G. VAlatin, reader in the University of Birmingham, has been appointed to the chair of theoretical physics, tenable at Queen Mary College. Dr. J. W. Bradbeer, lecturer in botany at the University College of Wales, Aberystwyth, has been appointed to the readership in botany tenable at King's College. 'The following titles have also been conferred: Professor, Dr. J. G. Clunie (pure mathematics, in respect of his post at the Imperial College of Science and Technology); Dr. H. I. Winner (bacteriology, in respect of his post at Charing Cross Hospital Medical School); Dr. G. H. Arthur (veterinary obstetrics and diseases of reproduction, in respect of his post at the Royal Veterinary College); Reader, Dr. P. Alexander (radiobiology, in respect of his post at the Institute of Cancer Research, Royal Cancer Hospital); Dr. I. M. Roitt (immuno-pathology in respect of his post at Middlesex Hospital Medical School).

\section{Announcements}

Mr. P. Parkin, an acoustics scientist at the Building Research Station, Garston, Watford, has received the Wolfe Award for 1964, for his work on acoustic design in buildings and his invention of 'assisted resonance' for modifying and improving hearing conditions in auditoria. It was presented by the secretary of the Department of Scientific and Industrial Research, Sir Harry Melville, at the Building Research Station on March 16. This award of $£ 500$ is the seventh of ten to be made annually under the terms of the Wolfe bequest to the research worker in the Department of Scientific and Industrial Research who makes an outstanding contribution to the research of the Department during the previous year.

Dr. R. W. Pringle, Dr. G. M. Brownell, Dr. K. I. Roulston and Dr. B. L. Funt were awarded the 1965 Inco Platinum Medal of the Canadian Institute of Mining and Metallurgy, at the annual general meeting of the Institute in Toronto, on March 30, for their development of the scintillometer and berylometer, instruments which have proved of great value in the exploration, development and exploitation of mineral and petroleum resources.

The annual Dale Lecture of the Society for Endocrinology will be delivered by Prof. A. S. Parkes at the Zoological Society of London on May 27. Further information can be obtained from Prof. I. Chester Jones, Department of Zoology, the University, Sheffield 10.

A CONFERENCE on "Structure and Control of the Melanocyte", organized under the auspices of the Research Commission of the International Union Against Cancer, will be held in Sofia during May 25-29. Further information can be obtained from Prof. N. Anchev, Oncological Institute, Sofia.

A MeEting on "Non-steroidal Anti-inflammatory Agents", arranged jointly by the Fine Chemicals Group and the Edinburgh Section of the Society of Chemical Industry, will be held in Edinburgh during May 28-29. Further information can be obtained from the Assistant Secretary, Society of Chemical Industry, 14 Belgrave Square, London, S.W.1.

AN international meeting on "Scientific and Practical Aspects of Colour" will be held in Lucerne during May 31-June 4. The programme will include sessions on: colour measurement; physiology; colorimetrics and colour systems; colour conditioning; calculation of dye recipes; colour and art; reproduction of colours; colour education. Further information can be obtained from the Secretary of the Swiss Organizing Committee for the International Colour Meeting, 1965, Seefeldstrasse 301, 8008 Zurich. 